\title{
What Is Groundwater? How to Manage and Protect Groundwater Resources
}

\author{
Patrick Lachassagne \\ HydroSciences Montpellier, University Montpellier, CNRS, IRD Montpellier, Montpellier, France
}

\section{Keywords}

Groundwater · Hydrogeology · Natural mineral water ·

Water cycle

\begin{abstract}
Among the water resources on earth, groundwater is a resource hidden in the rocks of the earth's crust. For various reasons, notably the fact that this water is not directly visible but also as a consequence of education and longstanding traditions, the properties and physical laws governing groundwater are not well known outside the circle of hydrogeologists, the scientists specialists of the survey, management, and protection of groundwater resources. This resource has lots of advantages, notably when compared to surface water, and is thus largely used worldwide for many purposes: agriculture, tap water, industries, bottling, etc. In fact, this resource is available year-long, even during the dry season and in arid countries, and is well protected from surface contaminations. It needs, however, to be appropriately managed and protected to ensure its sustainability (quantity and quality). Thus, this study intends to provide the basics of the groundwater science, "hydrogeology." It is illustrated by examples taken from the Evian Natural Mineral Water, that is groundwater, and the way it is managed and protected. The groundwater resource is a sustainable water resource belonging to the earth's water cycle, which flows thanks to the
\end{abstract}

natural energy provided by the sun. The main physical processes of the groundwater water cycle are the infiltration of rainwater into the soil, its slow flow within the pervious rocks from the earth's crust, called "aquifers," and finally its natural outflow at springs and into rivers. It can also be reached with man-made wells and pumped. Groundwater contains dissolved minerals that are mostly the results of interactions between the water and the aquifers' rocks.

(c) 2021 The Author(s)

Published by S. Karger AG, Basel

\section{Introduction}

It is important that clinicians and scientists working in hydration science are informed about groundwater for the main following reasons:

- Groundwater plays an important role in our modern economy, notably supplying, by order of decreasing volumes: agriculture (crops irrigation and, to a lesser extent, livestock), thus food production [1], domestic needs ("tap water"), and manufacturing.

- In most countries, groundwater is the main source for the domestic needs, then for mankind's hydration (a few percent of domestic needs in high income countries). For instance, in France, $>60 \%$ of tap water is groundwater, the rest being abstracted from surface water (rivers and lakes). karger@karger.com www.karger.com/anm

Karger $\stackrel{\text { ' }}{5}$

GOPEN ACCESS
(C) 2021 The Author(s)

Published by S. Karger AG, Basel

This article is licensed under the Creative Commons AttributionNonCommercial-NoDerivatives 4.0 International License (CC BYNC-ND) (http://www.karger.com/Services/OpenAccessLicense). Usage and distribution for commercial purposes as well as any distribution of modified material requires written permission.
Patrick Lachassagne

HSM, University Montpellier, CNRS, IRD

300, Avenue Pr. Jeanbrau

FR-34090 Montpellier (France)

patrick.lachassagne@umontpellier.fr 


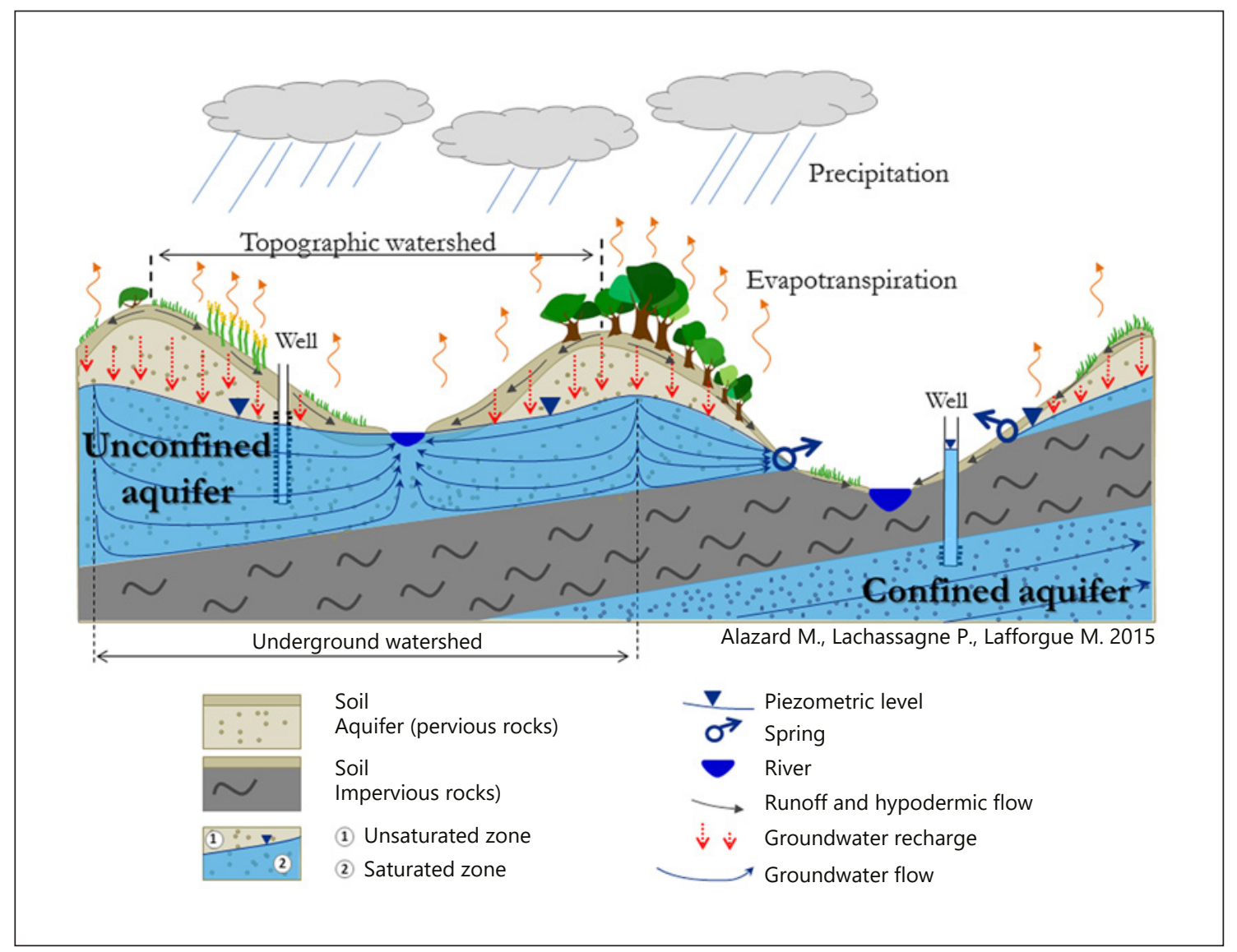

Fig. 1. Idealized cross section into the ground displaying some key elements and notions about the water cycle, and notably the groundwater cycle. (from [2])

- Bottled water is mostly "Natural Mineral Water" or "Spring Water," that, as a regulatory standpoint, must exclusively be abstracted from groundwater.

- Groundwater, that flows out from the rocks constituting the subsoil, is hidden, and, in most countries, not part of what students learn at school. It is, therefore, almost unknown from the public, as well as from most of the scientific community. Moreover, it is often subject to a lot of wild theories that must be fought.

Then, the main objective of this study was to provide the basics of the groundwater science, "hydrogeology." In fact, hydrogeology is a discipline of the Geosciences ${ }^{1}$ and involves scientists, as well as practitioners, "hydrogeologists," who are not at all "water diviners" but scientists

1 Geoscience is the scientific study of the Planet Earth and its many different natural geological systems (from https://geoscientistscanada.ca/profession-of-geoscience/what-is-geoscience/; last access: 2020 Mar 1).

2 The main definitions provided in this article are highlighted in bold. trained at the University, most with a Master to $\mathrm{PhD}$ degree. The illustration of this article principally relies on examples taken from the Evian Natural Mineral (Ground) Water. This article is complementary to another article published in this issue [1].

\section{Groundwater in the Water Cycle - Main Physical Processes Involved}

Groundwater is an important component of the water cycle. Solar energy ${ }^{2}$ is the energy that powers the water cycle; it enables water to evaporate (evaporation from sea water, lakes' water, and humidity at the surface of the ground) and, very importantly, it enables the vegetation to transpire water from the soil (the first few meters below ground surface where plants develop their roots), and transform this transpired water into vapor (evapotranspiration; Fig. 1). This water vapor is then circulated by
18

Ann Nutr Metab 2020;76(suppl 1):17-24 DOI: $10.1159 / 000515024$
Lachassagne 
the atmospheric currents (another consequence of the solar energy), and elevated to high altitude, which gives it a high potential energy. When the conditions are right, water vapor can condensate into liquid water droplets, that constitute the clouds, and that can gather into heavier drops and fall towards the ground, as precipitation (rainfall, snow, and hail); the liquid part of the water cycle begins (as opposed to the previous vapor part of the water cycle). The liquid part of the water cycle is "powered" by potential energy. In fact, whatever at the surface (surface water in the streams) or underground (groundwater), liquid water only flows thanks to its weight, that is linked to the Earth's gravity. Surface- and groundwater will then progressively lose potential energy along their pathway and, simply speaking, will flow from high to lower elevations. The water cycle is intimately linked to other cycles such as those of energy, carbon, solutes, etc.

Reaching the surface of the soil (Fig. 1), rainwater will infiltrate into it (infiltration). Part of this infiltrated water will be sucked into the soil due to the capillary forces existing at the surface of the grains constituting the soil (rocks' grains, minerals, and organic matter), and will there be attached to these grains; the drier the soil, the more newly infiltrated water will be retained on the soil's grains. This is mostly this "capillary water" that is aspired by the roots of the vegetation, used and transpired for its metabolism, and then resent back to the atmosphere as vapor (evapotranspiration; see above). Then, the hydrological definition of the soil is the very superficial layer of the earth's crust, decimeters to a few decameters thick, where the plants can abstract capillary water with their roots (Fig. 1). Due to this network of roots, but also due to animals (e.g., worms), which bioturbate the soil, most rainfall, even the more intense showers, can infiltrate into the soil. That is why, on natural soils, such as in a meadow, a forest, etc., it is rare to see an accumulation of water at the surface of the soil during a shower, as the soil can infiltrate large amounts of rainwater. In fact, soil has a high permeability $^{3}$ (or hydraulic conductivity). If rainfall is enough, part of the infiltrated water in the soil will escape the capillary forces of the soil's grains, and will follow 2 different paths.

This infiltrated water may find a lower permeability layer in the ground, at shallow depth (a few decimeters to a few meters). Then, it will follow the surface of this layer (=hypodermic flow, still as a result of gravity; Fig. 1) un-

\footnotetext{
3 The permeability characterizes how easily a liquid and/or a gas pass through a given material (here the soil). This is a quantitative parameter that can be measured.
}

What Is Groundwater? til it reaches again the ground surface, for instance, in a natural gully (a stream/river) or in a man-made ditch (Fig. 1). This water will then flow at the surface into this river or ditch; this is surface water. This water transfer is rather fast: the range is a few minutes to a few days between rainfall and apparition of surface water. This is the main process for creating floods and inundations when the surface water overflows from the riverbed.

The infiltrated water may not find a shallow low permeability layer in the ground. Then, it infiltrates deeper into the ground, vertically, to depths that can reach several meters, tens of meters, or even hundreds of meters, still as the consequence of the gravity (Fig. 1). It may then finally encounter a geological impervious layer, such as a clay layer for instance. There, the infiltrated water will "accumulate" above this layer; this is groundwater. The pervious rock that contains groundwater is called an aquifer. It comprises an unsaturated zone in its upper part, where the voids of the rock are only partly filled with water (flowing down), the rest being air. In its lower part, the aquifer also comprises a saturated zone where the voids of the rock are totally filled with water. The limit between both zones, that is the level of the surface of groundwater, is called the piezometric level. An aquifer with both an unsaturated zone and a saturated zone is called an unconfined aquifer. In some cases, groundwater can be kept under pressure in a pervious layer "confined" by an overlying impervious layer (Fig. 1); then, the aquifer is a confined aquifer. The infiltrated water that reaches the aquifer (confined or unconfined) is called the aquifer "recharge."

In fact, groundwater will not really accumulate in the ground, but it will flow into the permeable rocks, into the aquifers, until it reaches a place where it can outflow at the ground surface (Fig. 1): such places are known as springs; however, large volumes of groundwater also flow out along the banks of the rivers that cross aquifers (Fig. 1). Only a few aquifers, known as the "karstic aquifers," that develop in limestones, which are soluble rocks, have large voids (such as caves). Most aquifers owe their permeability to very small voids, less than a millimeter in radius, such as the voids existing between the grains of a rock composed of sand grains. These voids are called pores. As a consequence, in porous rocks, water is flowing in the entire body of the rock. Then, the notion of "an underground river" has no meaning in hydrogeology, except in karstic aquifers; even there "underground rivers" have important differences with surface water.

Then, the part of the continental water cycle between precipitation at the ground surface and discharge into the

Ann Nutr Metab 2020;76(suppl 1):17-24 DOI: $10.1159 / 000515024$ 
sea comprises 2 components: flow at the surface, in rivers, and underground, in aquifers. Below the level of the main rivers, and a fortiori below sea level, all rocks are fully saturated with (ground) water. Aquifers play 2 roles: storing groundwater and enabling it to flow; they can then be compared to a dam built on a river, as it also plays these 2 different roles, storage (in the dam) and flow (in the river on which the dam is built).

As there are lots of friction forces between groundwater and the aquifer rock, groundwater flow is very slow, down to only a few meters per year in some aquifers. Water transfers in aquifers can then last years, decades, or more. After groundwater has reached back the surface (at springs, in rivers bordering aquifers), it is again considered as surface water. Nevertheless, and notably during the dry season when precipitations cease for weeks or month, most of the rivers' flow is constituted by groundwater that infiltrated months or years before and feeds the rivers. One can then say that, during the low water stage, summer, surface water in rivers is groundwater. In some places, rivers have some "leaks" and recharge the underlying aquifers. Thus, along a flow path from rainfall to the sea, the water can alternate between traveling on the surface and underground. Surface- and groundwater belong to the same water cycle, and must therefore be considered as a whole. Thus, the flow of a river at a given time often comprises a fast component (the runoff) and a much slower one, resulting from the groundwater contribution.

Orders of magnitudes of the volumes of water stored on earth, including groundwater, as well as the various components of water flows, linked with the main climatic zones, are reported in [1]. More detailed explanations about the different components of the water cycle can also be found in [2].

\section{The Role of Groundwater for Ecosystems and Anthropogenic Needs}

Water is essential for human life, as well as for most ecosystems. As said above, most rivers owe their discharge during low flow periods to groundwater. This is crucial for the associated aquatic ecosystems, and all the ecosystems directly or indirectly related to these rivers. This is also crucial for several human activities: surface water uses, dilution of cities wastewaters, recreational activities, etc. Additionally, most wetlands owe their "wetness" to groundwater outflows.

Since time immemorial, human communities have settled near water sources such as perennial rivers, and springs. The latest provide water of much better quality than rivers as they are not polluted by upstream activities, such as divagation of animals in the riverbed or human waste. Moreover, groundwater is filtrated during its underground circulation and hence is safer, at least as a bacteriological standpoint, than surface waters. For millennia, in areas devoid of springs, men have learned to dig a few meters deep wells into the ground [3], to reach the piezometric surface of shallow aquifers and abstract good quality groundwater. More recently, since $<2$ centuries, and particularly since the second half of the 20th century, technological evolutions enabled to drill deeper wells that commonly exceed a 100-m depth (Fig. 1). Equipped with a submersible pump, such wells can provide up to $>100$ $\mathrm{m}^{3}$ of water per hour $24 / 24$. The discharge of such wells depends on the permeability of the tapped aquifer. When the water pressure (the piezometric level) in a confined aquifer is above ground surface, groundwater can naturally flow out at the surface and pumping may not be necessary (Fig. 1).

Beyond the interest in the quality of groundwater, it also has quantitative advantages. As it is stored in the ground, it can be abstracted whatever the season, and notably during the dry season when the discharge of rivers is very low, and surface water isn't available. In some countries, such as in Mediterranean regions or under semi-arid to arid climate, groundwater is often the only available water resource. Another advantage of groundwater is that wells can be drilled very near the place where the water is needed (city, farm, and industry), provided of course that an aquifer extends in the ground below that place. In fact, the access to groundwater is highly dependent on the local geological context. Then, costs for piping water from the groundwater source to the user can be reduced. However, as with all water resources, it must be managed to avoid overexploitation (i.e., pumping more than the natural recharge, and progressively impoverishing the groundwater stock) and, in some cases, it must also be protected to prevent any degradation of its quality.

\section{The Hydrogeological Science - Illustration with the Evian Natural Mineral Water}

Groundwater science, hydrogeology, has developed over the last 2 centuries; one can even consider that the first hydrogeologist was French [4]. Hydrogeology notably enables to define the precise location and to design (depth, diameter, and equipment) water wells, to forecast their future discharge, and to manage and protect the
Lachassagne 
groundwater resource. Scientists and practitioners are trained in engineering schools or at the university. They use methods such as geology and geophysics to understand the structure of the underground, hydrology, meteorology, hydrodynamics to forecast groundwater flowpaths and flows, and chemistry to understand its mineral content. Using such methods, they are able to well understand the structure and functioning of a groundwater system and its relationships with the surface.

In Evian for instance, research and studies performed over $>50$ years have enabled an excellent knowledge of the groundwater characteristics [5] (Fig. 2). The aquifer is composed of rocks (sands and tills) deposited by a glacier, several tens of thousands years ago, during the Quaternary glacial era. The aquifer recharge now occurs at high elevation on the Gavot Plateau. The Natural Mineral Water $(\mathrm{NMV})^{4}$ outflows at the Cachat spring in Evian several tens of meters above Lake Geneva, at the northern tip of the aquifer. These researches also enabled the delineation of the boundaries of the area on the Gavot Plateau where infiltrated precipitation can recharge the Evian aquifer, which is named the underground watershed (Fig. 1, 2). Its surface area is about $35 \mathrm{~km}^{2}$. The travel time of the groundwater in the aquifer, from recharge to outflow, is $>15$ years [5]. Such watershed delineation enables scientists to know where to protect the quality of the (rain) water that infiltrates to the aquifer and also to compute the annual amount of this recharge. Such a computation is essential to check that the amount of water abstracted at the spring and/or with wells does not exceed, on average, the natural recharge of the aquifer, the "groundwater budget." Thanks to numerical tools, similar to the one used for weather forecast, hydrogeologists are even able to simulate this water cycle, and notably its underground part, and to forecast various types of aquifer management scenarios. In some places of the world (see some examples in [1]), anthropogenic withdrawals in the aquifer exceed the aquifer recharge; the aquifer is overexploited, and its management is not sustainable; depending on the ratio (withdrawal - recharge)/storage, the aquifer will run out of water at short or longer term.

Hydrogeology also enables us to understand how and where the groundwater acquires its natural mineral content, that is the ions (or "electrolytes") naturally present in the groundwater. In Evian, this is mostly due to water-

\footnotetext{
4 "Natural Mineral Water" is a type of bottled water notably defined by the European regulation. It is exclusively pure groundwater, abstracted from an aquifer geologically protected from potential surface contamination, which mineral content is stable, bottled at the spring, etc.
}

What Is Groundwater? rock interactions, as infiltrated water dissolves and equilibrates with the rocks constituting the aquifer. The input from rainfall, notably with some salts coming from the sea (e.g., chloride), is a minority contribution. The other ions (e.g., calcium, magnesium, and bicarbonates) come from limestones (a rock composed of the calcite mineral, a calcium and magnesium bicarbonate) present in the aquifer, and from crystalline rocks, such as granite blocks that were brought from far away in Switzerland by the glacier to the Evian area, and that are now also constituting the aquifer (e.g., silica, sodium, and potassium).

\section{Protection of the Quality of Groundwater}

As explained above, groundwater is normally devoid of surface pathogenic microorganisms, principally as the infiltrated water is filtrated by the porous media constituting the soil and the underlying aquifer. A bad design or maintenance of the well or of the spring catchwork, enabling surface water to contaminate the groundwater, is the main cause of groundwater contamination by pathogens.

Other contaminants may affect the quality of water. They notably result from agricultural practices (e.g., organic contaminants such as pesticides and nitrogen), as agriculture often occupy large areas on a given watershed; such contaminations are qualified as "diffuse pollutions". Contaminations may also come from wastewaters from cities (and notably emerging contaminants such as pharmaceutical products and residues of drugs), and from industrial activities (e.g., hydrocarbons), which are often localized contaminations. Compared to surface water, groundwater is much better protected against these contaminations, notably as a large amount of these contaminants may be contained at the surface of the soil, biodegraded into it, or evacuated by the hypodermic flow. However, depending on both the anthropogenic pressure on a given watershed (the pollution hazard: type and amount of contaminant), and the physical characteristics of the soils and the concerned aquifer (the "intrinsic vulnerability" of the hydrogeological system), some aquifers may face risks and even be contaminated. Moreover, when a ground water contamination occurs, it often lasts a very long time (years, decades) as flow in aquifers are very slow, and the amount of water stored in most aquifers is large compared to their recharge. Thus, preventing groundwater contaminations must be privileged, rather than reacting after a contamination occurred. 


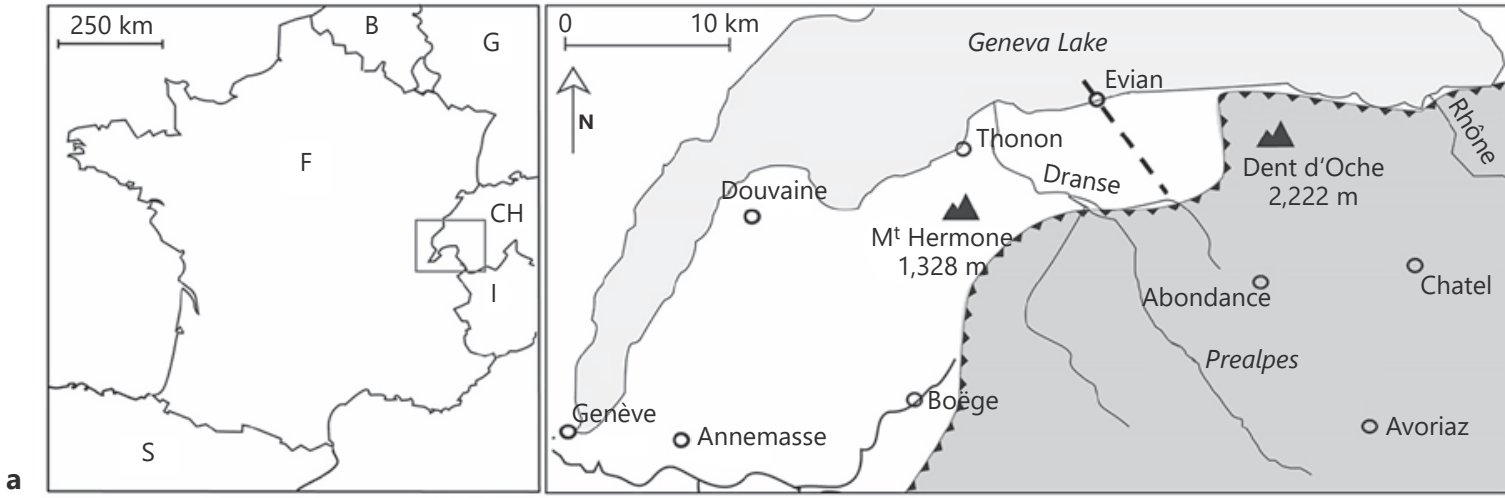

NNW

Boreholes: Gare Stade Tours Scionnex L5 elevation ( $m$ a.s.l.)

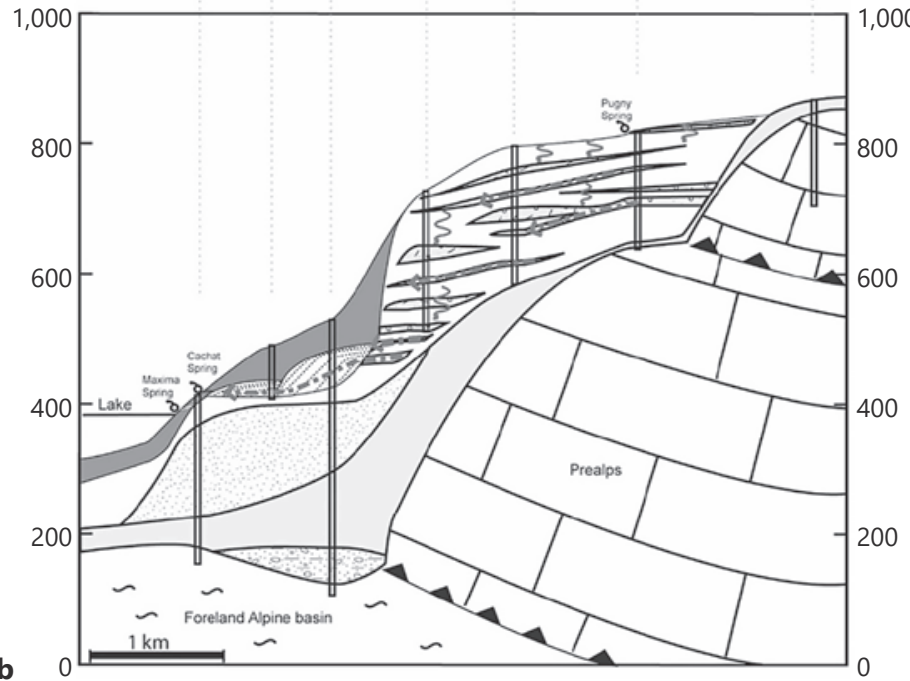

b

\begin{tabular}{|l|l|l|l|}
\hline Pebbles and sands (kame terraces) & \multicolumn{2}{c}{ Absolute ages } \\
(B.P.)
\end{tabular}

Fig. 2. Hydrogeological cross section of the Evian aquifer, French Alps. a Location of the cross section of $\mathbf{b}$ (dotted line). $\mathbf{c}$ Legend. (from [5]) 
Fig. 3. Main principles of the APIEME which main objective is the protection of the Evian, French Alps, Natural Mineral Water. (from [6])

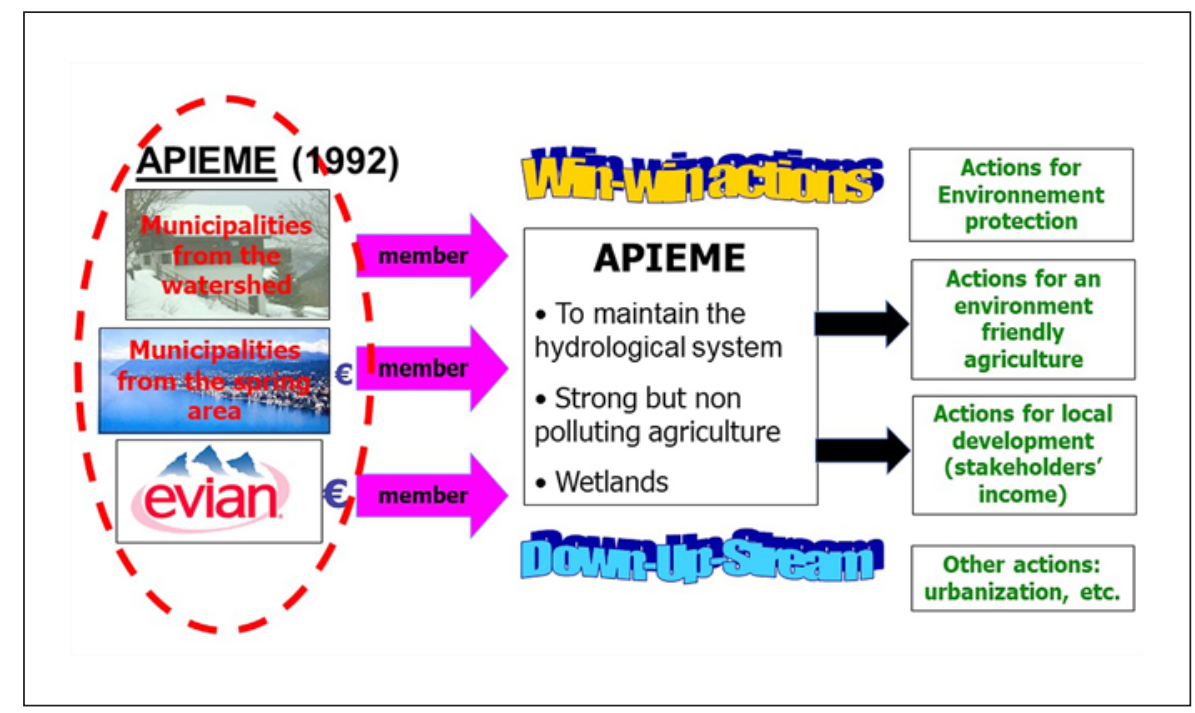

As an example, in order to guarantee the long-term purity of the Evian NMW, and to complete the natural geological protection of the aquifer, protection policies have been implemented on the Evian watershed for about 30 years [6]. Of course, the sustainable quantitative management of the NMW resource is a prerequisite to any protection policy. This quantitative aspect was addressed previously in this article.

Natural protection is not only related to soils and aquifer protection but also to the type of land use/activities existing on the watershed. In Evian, the land use is dominated by meadows, forests, wetlands, etc., which help to improve the quality of surface and infiltrated waters.

Thus, Evian established an original partnership policy on the Evian NMW watershed (the plateau de Gavot, with a surface area of $35 \mathrm{~km}^{2}$, located at an altitude of between 800 and 1,200 m amsl), forming the Association pour la Protection de l'Impluvium des Eaux Minérales d'Evian (APIEME), the Association for the protection of the Evian NMW watershed, back in 1992 (Fig. 3) ${ }^{5}$.

This association operates like a local water parliament. It brings together:

- the mayors of the 9 municipalities located on the watershed,

- the mayors of the 4 municipalities with NMW springs,

- the Société Anonyme des Eaux Minérales d'Evian (SAEME), the company that bottles the NMW.

\footnotetext{
5 See for instance: https://www.cc-peva.fr/354-l-impluvium-des-eaux-devian.htm, http://www.apieme-evian.com/ (last access: 2020 Mar 7).
}

The association's role is to design and fund projects, practices, and developments deemed useful for effective, long-term protection of the NMW resource but also to favor local economic development and the well-being of the population living on the watershed.

Two-thirds of the association's funds come from the SAEME and one-third from the 4 municipalities benefiting from NMW springs. Under French tax laws, these municipalities having a NMW spring/well on their territory benefit from a special financial contribution, the "bottling" tax that comes on top of the other taxes paid by any industry to the state or municipalities. The municipalities in the Evian spring area have thus agreed to dedicate a percentage of this bottling tax to fund the association, and hence to the long-term protection of Evian NMW quality.

The APIEME is managed like any other association, with each member having one vote and electing a board. Through its democratic operating system, the APIEME has developed a policy of downstream to upstream economic redistribution, based on highly technical projects and in-depth knowledge of the area, all of which need to be "win-win" for all parties: NMW protection, to maintain the water company's business and the tax incomes of the municipalities in the spring area, while ensuring the economic development of the municipalities in the watershed area. These projects are multisectoral. They, therefore, help to fund actions in the fields of agriculture, town and country planning, wastewater treatment, preservation of natural areas, etc. They focus exclusively on actions with a collective impact (no "per hectare" subsi- 
dies in agriculture, e.g.). They do not result in a land ownership policy for the water company, as the watershed remains the property of its inhabitants and other social/ economic categories (farmers and forest owners).

After several years of informal discussions, the Memorandum of the Association was agreed in 1992 and is still in place and relevant now. Its first task was to prioritize and allocate funding to local actions to the 3 main sectors that are locally, namely, agriculture, villages, and their infrastructures, and wetlands (Fig. 3). Another less visible but important role is to create a forum where these stakeholders can discuss local environmental or water issues and possible improvements. Communication on the objectives, awareness campaigns, and environmental education to environment complete the association's scope.

\section{Conclusion}

Groundwater is a sustainable water resource belonging to the earth's water cycle, which flows thanks to the natural energy provided by the sun. The main physical processes of the groundwater cycle are the infiltration of rainwater into the soil, its slow flow within the pervious rocks constituting the earth's crust, and finally its natural outflow at springs and into rivers. It can also be reached with man-made wells and pumped. Groundwater contains dissolved minerals that are mostly the results of interactions between the water and the aquifer's rocks. This resource has lots of advantages, notably when compared to surface water, and is thus largely used worldwide for many purposes: agriculture, tap water, industries, bottling, etc. It needs, however, to be appropriately managed and protected to ensure its sustainability (quantity and quality). Hydrogeologists, the scientists, and practitioners of groundwater are the specialists of the survey, management, and protection of groundwater resources.

\section{Statement of Ethics}

This research did not involve human studies and therefore does not need to comply with the guidelines of human studies.

\section{Conflict of Interest Statement}

This article is derived from a presentation made during the 2019 H4H conference in Evian. The author, P. Lachassagne, was then an employee of Danone Waters. The writing of this article was then partly supported by Danone Research, and the author declares no other conflicts of interest.

\section{References}

1 de Marsily G. Will we soon run out of water? Ann Nutr Metab. Forthcoming. 2021.

2 Lachassagne P, Rouquet S, Lafforgue $\mathrm{M}$. Chapter 1.2: main quantitative hydrological concepts, and forest hydrological concepts. In: Lachassagne P, Lafforgue M, editors. Forest and the water cycle: quantity, quality, management. Newcastle upon Tyne, UK: Cambridge Scholars Publishing; 2016. p. 2338.
3 Rybníček M, Kočár P, Muigg B, Peška J, Sedláček R, Tegel W, et al. World's oldest dendrochronologically dated archaeological wood construction. J Archaeolo Sci. 2020;115: 105082.

4 Paramelle J-B. The art of finding springs: a translation of L'Art de Découvrir les sources. 2nd ed. Geological Society of America

5 Blavoux B, Lachassagne P, Henriot A, Ladouche B, Marc V, Beley J-J, et al. A fifty-year chronicle of tritium data for characterising the functioning of the Evian and Thonon (France) glacial aquifers. J Hydrol. 2013;494:116-33.
6 Beley JJ, Lachassagne P, Perfetti JC. Chapter 6.5: the principle of Danone waters natural mineral waters (NMW) protection policies. Forest development and NMW protection in the Volvic, France, impluvium. In: Lachassagne $\mathrm{P}$, Lafforgue $\mathrm{M}$, editors. Forest and the water cycle: quantity, quality, management. Newcastle upon Tyne, UK: Cambridge Scholars Publishing; 2016. p. 552-69. 